\title{
A Study on Merger and Operating Performance of Commercial Banks of Nepal"
}

\author{
Sajena Dwa and Ajay Kumar Shah ${ }^{2}$
}

\begin{abstract}
This study aims to find the impact of mergers on operating performance of sample merged banks. To attain the research objective, this study has taken 8 independent variables; operating profit margin, net profit margin, return on assets, return on equity, debt equity ratio, return on loan loss provision, return on staff expenses and return on operating expenses. Three cases have been taken for the study as a sample to examine whether merger has led to a profitable situation or not. Research mainly focuses on quarterly secondary data which is analyzed using paired sample t-test, correlation analysis, VIF test and regression analysis. From the analysis it is deduced that merger has no significant role in case of Nepal Bangladesh Bank and NIC Asia Bank in terms of various operational ratios, since many operational ratios have been found weaker in post-merger period than pre-merger period. But merger plays a significant role in case of Machhapuchchhre Bank where almost all operational ratios have improved in post-merger. While analyzing the situation of overall commercial banking sectors, with the help of sampled data, it is observed that largely the merger isn't able to produce positive results for the merged entities. The study shows the reason for negative result of merger as the poor financial position of the target banks. Further the merger will somewhat act as a solution for the current problems of Nepalese BFIs. Merger will be a wise option to bring BFIs in strong and growing position and to meet the requirement of current paid up capital as per the latest NRB directive. But it also must be considered that merger in itself is not the ultimate solution to strengthen the financial position of BFIs. A lot of factors must be taken into account before finding the right partner to merge with and executing the merger.
\end{abstract}

Keywords: NRB; ratio analysis; paired sample t-test; regression; secondary data and descriptive analysis.

\section{Introduction}

Mergers and acquisitions have long been prevalent across the globe. The Nepalese financial sector has witnessed a tremendous growth in the number of financial

The earlier version of this paper was presented in an International Conference on Business, Society and Governance: Emerging Management Paradigm (INCONBS) on 28th Feb, 2017

Ms. Dwa is an MBA graduate of Ace Institute of Management, Affiliated to P.U., Nepal.

2 Mr. Shah is a Research Director at Ace Institute of Management and PhD Scholar of Finance at Kathmandu University

Corresponding Email: ajayshah@ace.edu.np, imajayshah@gmail.com 
institutions after the 1980's by adopting an economic liberalization regulation with a mixed economic model. However, the unnatural increment of the BFIs has brought several financial challenges and complexities. The financial indicator has indicated that the Nepalese financial sector is weak, vulnerable and at the verge of a collapse.

The central bank planned to improve the health of the financial sector by introducing the Merger by law 2011 grounded on the Company Act 2006 article 177, BAFIA 2006 article 68 and 69 that pressurize all the BFIs for immediate merger as a consolidation (Adhikari, 2014). A merger was not a choice of the Nepal Rastra bank but it was a compulsion strategy to increase the capital and strengthen their capacity to face the competitive market.

It is perceived that, merger will result in newer and larger organizations which are supposed to be efficient in allocating resources, human and capital and maximize the output gains. It is believed that the larger banks, with more resources can offer more products and services at lesser operating cost i.e. at economies of scale. However, the perceived gains do not occur, at least not to the extent that is perceived. Some of the genuine impacts or effect of mergers on the banking industry can be observed around the world, which has been the reduced availability of loans to the customer base after merger. It is mainly because of decline in competitiveness in banking industry and increase in the interest rates above reasonable level. Banks have been observed to be engaged in activities ranging from anti-competitiveness to corruption after the merger. When economies of scale are observed, there is a significant uncertainty over how wide the range of scale is. There is often increase in dissatisfaction among employees after merger of the institutions. A lot of issues can be found in the management of staff after the merger.

Bank merger is something of novelty for Nepal, but it has long history in other countries. Merger in Nepal is horizontal merger because merger is happening between two or more firms which are operating in similar kind of business. For the development of banking system in Nepal, NRB refreshed and changed financial sector policies, regulations and institutional developments in 1980 A.D. Government emphasized the role of the private sector for the investment in the financial sector. These policies opened the doors for foreigners to enter into banking sector in Nepal under joint venture (Sharma, 2014).

The overwhelming outgrowth and the rapid surge of BFIs have not only led to the malpractice of banking norms and unfair competition but also have created such situation where it is difficult for NRB itself to grab the situation due to its own limitations. The policy adopted by the NRB has started to pay back with the increase in the numbers of bank and financial institution for merger to improve 
their performance and become strong in such competitive market but proper studies have not done yet to identify whether merger helps to improve financial performance and makes them strong.

The major motivation behind this study is, after the NRB introduced the Merger by law 2011 to increase capital base, how is the present operating performance of the banks and financial institutions that have been merged in Nepal? Are these banks really performing well after the merger or there is negative impact of merger in the operating performance of the institution?

This study seeks to identify the difference between pre and post-merger operating performance of commercial bank, the relationship between influencing factors and financial performance of commercial banking sector and scrutinize the success/failure of mergers in Nepalese Banking Industry.

After studying multiple articles, besides few unpublished thesis and papers, the researcher is unable to find a published paper on merger and its impact on the commercial banking sector in Nepal. As a result the researcher has taken Mantravadi and Reddy's (2007) "Relative size in mergers and operating performance: Indian experience" as the key paper. Researcher has selected most of the operating performance variables from the same and attempted to analyze the data as analyzed in the key paper. But despite having huge similarities, result is slightly contrasted with key paper which has suggested that relative size of merged or acquired institution is the main factor for success of merger but this study suggests that despite of its size, its financial health and proper synchronizing of merging institutions are more important factors for a successful merger. The reason behind the contrast in the result may be categorization of institutions on the basis of their relative size by Mantravadi and Reddy (2007) and random selection of three merged banks by the researcher.

The outcome of this study will be primarily beneficial to policy makers, to rethink whether the results are as intended when the policy was originally introduced. Besides them the study will also prove beneficial to many stakeholders in the banking industry of Nepal. The banks that are being merged in future will have an overview of the condition and impact of mergers in the country and make possible strategies to make it successful. Besides that, investors will have an overview of the impact of mergers in the Nepalese banking industry. They will be able to analyze the trends and growth of the banks being merged and pull out or invest more money in the banks according to their interest. With the help of this paper, researcher is trying to identify the areas where the merged banks are doing good and where they are going down which can be taken as a reference by the banks to be merged in future and can work upon those factors which may take down the performance of the bank. 
The remaining part of the paper is organized as follows; the second section includes review of past literature. The third section deals with the model and methods. The fourth section discusses about the analysis of data and its presentation and the fifth section makes concluding remarks.

\section{Review of the Literature}

The wave of merger between BFIs is going on in Nepal, but besides few unpublished research, it is difficult to find published articles in context of Nepal. The research paper published by NRB (2015) "Post-merger status of banks and financial institutions and the effectiveness of merger" is limited in the sense that it has not established hypothesis and thus have not tested any and is mainly based on primary data which is subjective as stated in its limitations. However, plenty relevant researches have been conducted in the countries with similar economic indicators as Nepal and in other developed economies, hence, the findings of these global researches are taken as a literature basis for this research.

Peristiani (1997) has focused on central issue currently debated among bank analysts and economists. This paper investigates the post-merger performance of acquiring banks that participated in a merger during the period 1980-90. The paper uses regression analysis to identify factors influencing the performance of merging banks. The regression results suggest that improvements in post-merger performance depend on the ability of the bank to strengthen asset quality. They find no evidence to support the theory that in market mergers lead to significant improvements in efficiency.

Cornett, McNutt and Tehranian (2006) have conducted a study to evaluate the changes in the performance of banks after mergers with the help of revenue enhancements and the cost reductions. They find that industry-adjusted operating performance of merged banks increases significantly after the merger, large bank mergers produce greater performance gains than activity diversifying mergers, geographically focusing mergers produce greater performance gains than geographically diversifying mergers and performance gains are larger after the implementation of nationwide banking in 1997. Further, they find improved performance is the result of both revenue enhancements and cost reduction activities. However, revenue enhancements are most significant in those mergers that also experience reduced costs.

Pazarskis et al. (2006) have investigated the impact of corporate merger over the operating performance of Greece manufacturing acquiring firms. In this study the financial performance is evaluated by using financial and non-financial variables. Financial performance measurement is with financial ratios which are divided into the group namely profitability, liquidity and solvency. The main interesting finding 
of the survey is that there is strong evidence that the profitability of a firm that performed an M\&A is decreased due to the merger/acquisition event.

Mantravadi and Reddy (2007) have aimed at analyzing the post-merger operating performance for acquiring firms in Indian industry during the post-reform period, from 1991-2003, which was expected to provide large sample size across industries. The post-merger operating performance of acquiring firms for different relative sizes (of acquiring and acquired firms) was analyzed to see if differences in sizes of acquiring and acquired firms can cause a different impact on the outcome compared to general results of merger studies. They have evaluated the impact of merger on the operating performance of acquiring firms in different industries by using pre and post financial ratios to examine the effect of merger on firms. They have selected all mergers involved in public limited and traded companies in India between 1991 and 2003 and the result has suggested that there is little variation in terms of impact on operating performance after mergers. In different industries in India particularly banking and finance industry have a slightly positive impact of profitability. Some of the industries have a significant decline both in terms of profitability and return on investment and assets after merger.

Altunbas and Marques (2008) have observed the impact of strategic similarities between bidders and targets on post-merger financial performance. This article shows that on average, bank mergers in European Union have resulted in improved return on capital. They ran the empirical analysis by using an extensive sample of individual bank mergers which in turn, was linked to individual bank accounting information. They have found that there are improvements in performance after the merger has taken place particularly in the case of cross-border mergers. In terms of the impact of strategic relatedness on performance, the overall results show that broad similarities among merging partners are conducive to an improved performance, although there are important differences between domestic and crossborder mergers and across strategic dimensions.

Mantravadi and Reddy (2008), have done the study to understand which type of mergers have been more successful in improving the performance of merging firms, among horizontal mergers, vertical mergers and conglomerate mergers. The research study has adopted the methodology of comparing pre and post-merger performance of merging companies by using operating profit margin, gross profit margin, net profit margin, return on net worth, return on capital employed and debt equity ratio. The pre-merger (for three years prior to merger) and post-merger (for five years after the merger) averages of financial ratios are compared, and tested for differences, using paired " $\mathrm{t}$ " test for two samples. Comparison of post vs. premerger operating ratio, for the different types of mergers suggested that horizontal mergers have caused the highest decline in the operating performance of the merging companies, followed by conglomerate and vertical mergers, in that order. 
Kemal (2011) has studied the post-merger profitability of Royal Bank of Scotland where he has used accounting ratios to analyze the financial performance of Royal Bank of Scotland (RBS) in Pakistan after merger with an aim to find out the answer of "Does merger of the banks improves the profitability?" The report has analyzed their financial statements for four years (2006-2009) by using 20 vital ratios which includes the ratios from profitability, liquidity, market value etc. The results show that the financial performance of RBS in the areas of profitability, liquidity, assets management, leverage and cash flows has been quite satisfactory before the merger deal. It means that merger deal fails to improve the financial performance of the bank. This conclusion may not be the result for all the banks, as others may gain profit or increase profitability from the mergers. But in case of this report of RBS in Pakistan, merger does not work for it.

Rani, Yadav and Jain (2015), in their paper, have investigated the impact of mergers and acquisitions (M\&A) on corporate performance. It compares performance of the corporates involved in M\&A before and after M\&A. From the paper, they concluded that acquiring firms in India appears to have performed better after M\&A in comparison to their performance before M\&A, primarily due to reduced cost, economies of scale and operational synergies.

Abdulazeez, Suleiman and Yahaya (2016), have examined the impact of mergers and acquisitions on the financial performance of some selected deposit money banks in Nigeria from 2002 to 2008. They have used returns on asset and return on equity of the selected banks to measure the financial performance of the banks before and after consolidation. Data for the study are analyzed using t-test statistics and it is revealed that the bank witnessed improved and robust financial performance owing to merger and acquisition leading to more financial efficiency in the Nigerian banks. The study recommends that banks should be more aggressive in financial products marketing to increase financial performance in order to reap the benefit of post mergers and acquisition bid in the Nigerian banking sector.

As observed from the literature review we cannot find much research being done on Nepalese Banking Industry. A thesis paper researched by Adhikari (2014) on "Merger and Acquisition as an indispensable tool for strengthening Nepalese Banking and Financial Institutions" focuses on the impact of merger on the different stakeholders such as employees, shareholders and customers and uses earning per share (EPS) and market value per share (MVPS) to evaluate the financial position of merged entities. It doesn't provide an in-depth analysis of the financial situation of the merged banks, both pre and post-merger. Secondary analysis has not been done much in the past due to unavailability of data. But in this paper researcher has attempted to analyze the impact (pre and post analysis) of 
merger with the help of secondary data. So, the present paper would go to investigate the details of Mergers with a great focus on Nepalese Banking Industry. The study discusses the pre and post-merger operating performance of the selected banks in terms of various ratios such as, operating profit margin, net profit margin, ROA, ROE etc.

In addition to the paper by Adhikari (2014), a research paper published by NRB (2015), has performed an exploratory research to study the impact of merger on banks and financial institutions. NRB has used primary data from 550 respondents and secondary data for 3 years of pre- and post-merger period of 25 merged entities. The study concludes that major reason for financial institutions to go into merger is to increase their paid-up capital, expand the operational area as well as decrease the competition. Although the merger has positive changes in the employee satisfaction and work culture, it has created a delay in the process of decision making. The 6 financial indicators that NRB has used indicate a mixed result for the first two years i.e. positive changes in some BFIs and negative in some but when the $3^{\text {rd }}$ year starts after merger the financial indicators show improvement for all the merged BFIs.

Through the current study it is identified that merger is not always profitable. The resulting profitability or loss varies according to the financial strength and operations of the merging entities. Although NRB introduced the merger by laws 2011 to strengthen BFIs, the results show otherwise. But still the hype to continuously merge for the sake of meeting NRB regulations is ongoing making BFIs more vulnerable to resulting decline in profitability.

\section{The Methodology}

This section basically deals with the conceptual framework, methodology and models used for the study.

\subsection{The Basic Model}

According to Shrestha (2012), the concept of M\&A was an entirely new thing to the Banking and Financial Institutions (BFIs) of Nepal when the Nepal Rastra Bank, supervisory and regulatory body of all the BFIs has issued merger by-laws in May 2011. "It is something in which Nepal Rastra Bank has been preparing for years" (Gyanwali 2011). However, many had doubts that the BFIs would go for merger immediately as there were no separate acts and decree for a merger implementation. The objective of the merger by-laws is to strengthen the BFIs position and performance by reducing the number of institutions. The merger by laws has a provision that can pressurize all BFIs to go for an immediate merger in the form of consolidation (Share Bazar Nepal, 2013). Merger transactions are increasing in Nepal over the few years. Especially with the Central Bank of 
Nepal's mandate for the merger of Bank and Financial Institutions, number of Mergers happening in Nepal is increasing day by day.

Among the above mentioned reviews of the papers by various authors, Mantravadi and Reddy (2007)'s paper seems to be more similar to the research conducted in this study. The conceptual framework is based on the paper. The paper has compared the pre and post-merger operating performance of various banks on the basis of some variables like operating profit margin, gross profit margin, net profit margin and return on net worth, return on assets and debt-equity ratio. They have compared the level of significance between pre and post-merger financial health of the selected banks using paired sample t-test and found that banking sectors have shown some positive impact on profitability and other sectors are either in same condition or have negative impact on operating performance.

\section{Diagrammatically}

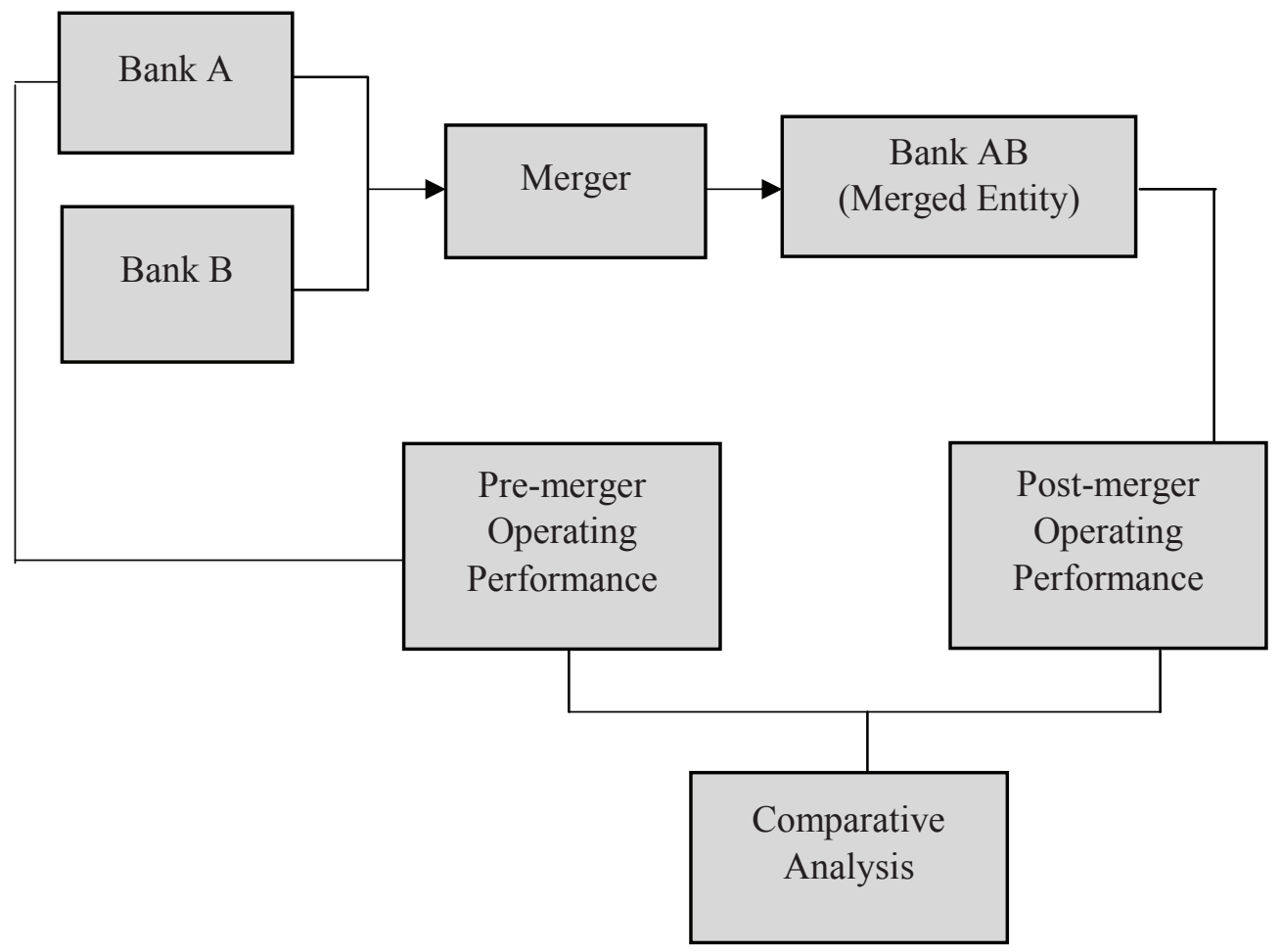

Figure 1: Conceptual framework for the study 


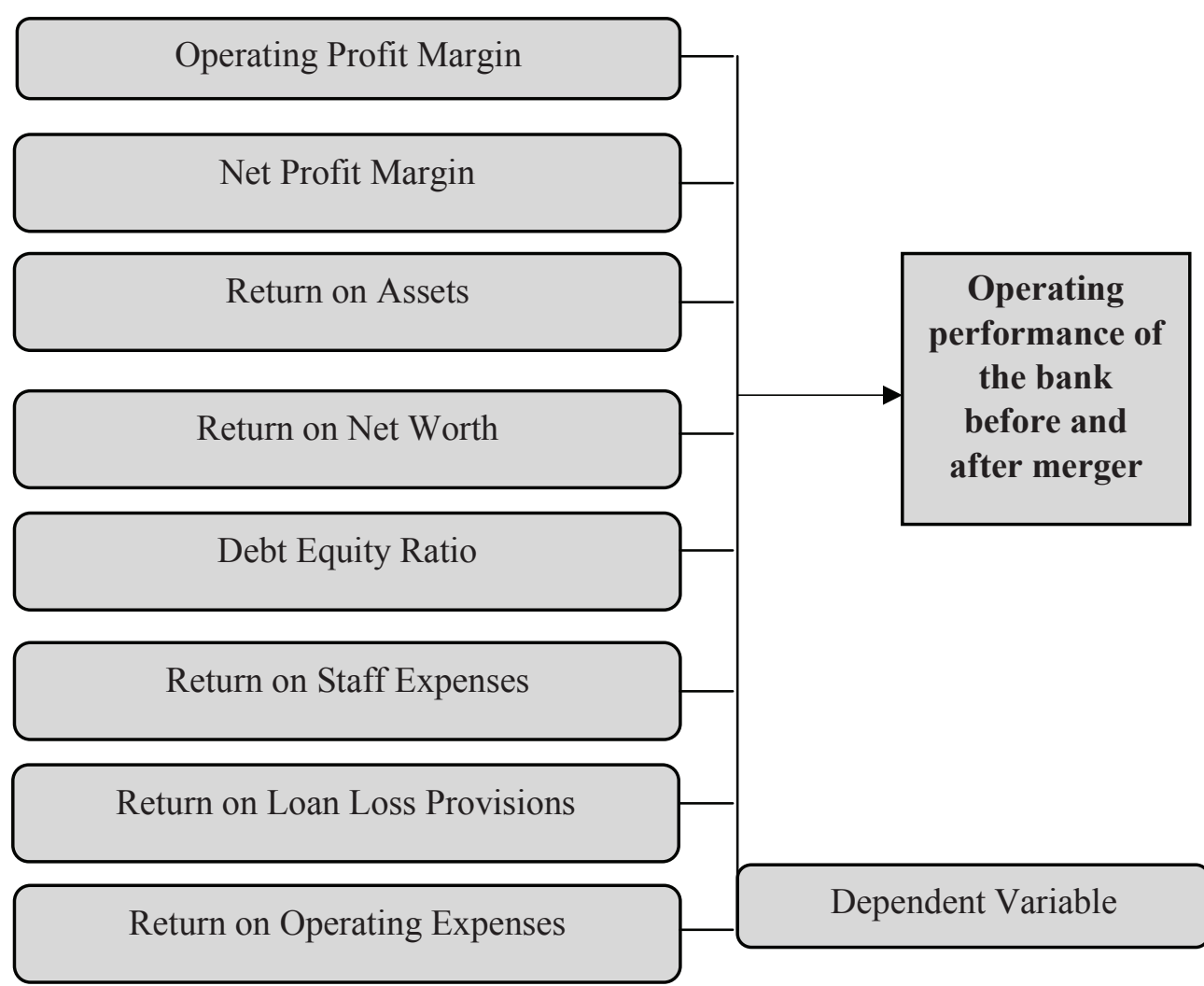

Independent Variable

\section{Figure 2: Conceptual framework for the study}

\section{Functionally}

The conceptual framework can be further materialized into a functional form as below;

$\mathrm{Q}=\mathrm{f}\left(\mathrm{X}_{\mathrm{i}}\right)$, Where $\mathrm{i}=1,2,3, \ldots \ldots, 8$

Where,

i.e. $Q=f\left(X_{1}, X_{2}, X_{3}, \ldots ., X_{8}\right)$

$\mathrm{Q}=$ Operating performance of the bank

$\mathrm{X}_{1}=$ Operating Profit Margin

$\mathrm{X}_{2}=$ Net Profit Margin 


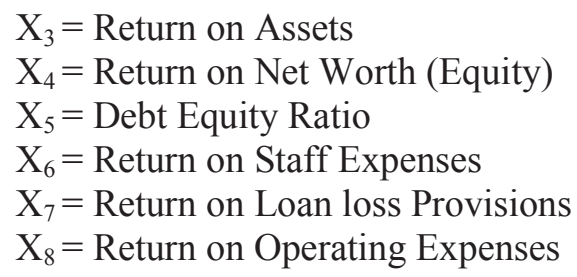

\subsection{The Data}

The present study has been conducted by following a descriptive design where an attempt has been made to measure the impact of mergers on the operating performance of Nepalese bank being merged. The study is based on secondary data collected from various annual reports of several banks, official website of Nepal Rastra Bank, magazines, journal and other published documents. This paper covers the study of operational performance of the bank before and after being merged. By October 17, 2016 all the banks and financial institutions have been merged into 12 commercial banks.

Since all mergers cannot be studied and analyzed, based on data availability and time constrain, the researcher has studied these three merged entities on the basis of convenience and judgmental sampling technique. Based on NRB's research paper (2015) that has used the 3 years pre- and post-merger data, the researcher has also chosen to use minimum of 3 years data. For the required time period only the following three banks have the financial data:

Table 1: The sampled BFIs

\begin{tabular}{|c|c|c|c|}
\hline $\begin{array}{l}\text { Serial } \\
\text { No. }\end{array}$ & Pre-Merger & Post-Merger & $\begin{array}{l}\text { Time } \\
\text { Period }\end{array}$ \\
\hline Case & Nepal Bangladesh Bank Limited \& Nepal & Nepal Bangladesh & \\
\hline & Srilanka Merchant Finance Limited & Bank Limited & 5 Years \\
\hline Case & Machhapuchchhre Bank Limited \& Standard & Machhapuchchhre & \\
\hline & Finance Limited & Bank Limited & 4 Years \\
\hline Case & NIC Bank \& Bank of Asia Nepal & $\begin{array}{l}\text { NIC Asia Bank } \\
\text { Limited }\end{array}$ & 3 Years \\
\hline 3 & & Limi & 3 Y ears \\
\hline
\end{tabular}

For the tabulation analysis of the collected information, Microsoft Excel and SPSS are used. In this research data has been collected through various sources i.e. quarterly reports of banks of several periods which are arranged in MS-Excel so that they can be further used in SPSS for analyzing data. The data in the excel sheet is presented in the percentage form rather than in exact figures because the figures vary according to the size and operations of the company. 
Since the data required for the study is available entirely in the quarterly reports of the companies and those quarterly reports are verified by the government appointed auditors, there is a strong belief that the data is totally reliable and valid. Also, all the data are collected from official websites of the selected banks which eliminates the chances of data being manipulated.

\subsection{The Analytical Procedure}

The various statistical tools and techniques have been applied to analyze the collected information in this study. Mean and standard deviation are used for descriptive statistics and paired sample t-test for inferential statistics. Correlation analysis and VIF test are carried out to identify multicollinearity in the independent variables for regression. Regression analysis is used to identify the significance of operating ratios on profit position of commercial banking industry. The data has been analyzed with the help of SPSS and MS-Excel. Pre and post-merger performance ratios are computed for the sample banks which have gone through merger. The pre and post M\&A performance ratios are compared to see if there is any statistically significant change in performance of merged firm after M\&A, using "paired sample test" at confidence level of 0.05 or $95 \%$. As there are no published articles to study the impact other than that of NRB, which hasn't tested any hypothesis, this research will test the positive or negative significance of merger based on different operating ratios.

\section{Result and Discussion}

This section deals with the analysis of the secondary data to meet the objective of the study. In section (4.1) paired sample t-test of the ratios is done to determine whether the merger has proved to be significant or not in improving performance of the BFIs post-merger. In section (4.2) correlation and regression analysis is performed to identify the significance of operating ratios on profit position of commercial banking industry.

\subsection{Summary Statistics}

The tables below give the mean values and the standard deviation for each variable in the study. For inferential analysis, paired sample t-test is used which compares the mean scores of two groups on a given variable. The paired sample t-test is usually based on groups of individual, who experience both conditions of variable of interest. As the objective of this research is to evaluate the impact of mergers on the operating performance of the selected three banks and the whole commercial bank sector drawing conclusions from the sample, paired sample t-test is chosen as a best statistical tool for the analysis according to the nature of data available from various bank's financial highlights. 
Table 2: Paired sample t-test of operating ratios of Nepal Bangladesh bank limited

\begin{tabular}{|c|c|c|c|c|c|}
\hline Particulars & Period & Mean & $\begin{array}{l}\text { Std. } \\
\text { Deviation }\end{array}$ & t-value & $\begin{array}{l}\text { P- } \\
\text { Value }\end{array}$ \\
\hline Operating Profit & Pre-Merger & 34.12 & 20.02 & \multirow{2}{*}{3.59} & \multirow{2}{*}{0.002} \\
\hline Margin & Post-Merger & 21.76 & 14.03 & & \\
\hline Net Profit & Pre-Merger & 81.59 & 60.62 & \multirow{2}{*}{4.12} & \multirow{2}{*}{0.001} \\
\hline Margin & Post-Merger & 28.25 & 11.61 & & \\
\hline Return on & Pre-Merger & 4.50 & 5.28 & \multirow{2}{*}{2.88} & \multirow{2}{*}{0.01} \\
\hline Assets & Post-Merger & 1.43 & 1.10 & & \\
\hline Return on & Pre-Merger & -2.95 & 137.05 & \multirow{2}{*}{-0.43} & \multirow{2}{*}{0.671} \\
\hline Net Worth & Post-Merger & 10.15 & 7.53 & & \\
\hline Debt Equity & Pre-Merger & 65.61 & 2129.51 & \multirow{2}{*}{-1.19} & \multirow{2}{*}{0.248} \\
\hline Ratio & Post-Merger & 629.39 & 72.34 & & \\
\hline Return on & Pre-Merger & 624.95 & 536.38 & \multirow{2}{*}{3.60} & \multirow{2}{*}{0.002} \\
\hline Staff Expenses & Post-Merger & 210.12 & 88.05 & & \\
\hline Return on & Pre-Merger & 504.27 & 429.22 & \multirow{2}{*}{1.67} & \multirow{2}{*}{0.111} \\
\hline Loan Loss Provisions & Post-Merger & 387.54 & 374.80 & & \\
\hline Return on Operating & Pre-Merger & 333.52 & 287.42 & \multirow{2}{*}{3.50} & \multirow{2}{*}{0.002} \\
\hline Expenses & Post-Merger & 115.91 & 47.98 & & \\
\hline
\end{tabular}

Using the paired sample t-test, the quarterly data of 5 years of pre and post-merger are analyzed for Nepal Bangladesh Bank Limited. From the table, for majority of the operating ratios i.e. 6 out of 8 the mean value seems to have reduced in the post-merger period indicating decline in performance after the merger. The p-value less than 0.05 denote significant difference between pre and post-merger operating ratios. The p-values of Operating profit margin, Net profit margin, return on assets, return on staff expenses and return on operating expenses indicate a significant difference between pre and post-merger performance, where the performance has significantly declined.

Table 3: Paired sample t-test of operating ratios of Machhapuchchhre bank limited

\begin{tabular}{|c|c|c|c|c|c|}
\hline Particulars & Period & Mean & $\begin{array}{l}\text { Std. } \\
\text { Deviation }\end{array}$ & t-value & $\begin{array}{l}\text { P- } \\
\text { Value }\end{array}$ \\
\hline Operating Profit & Pre-Merger & 6.51 & 9.14 & \multirow{2}{*}{-1.57} & \multirow{2}{*}{0.138} \\
\hline Margin & Post-Merger & 15.89 & 15.69 & & \\
\hline Net Profit & Pre-Merger & 5.95 & 5.45 & \multirow{2}{*}{-2.57} & \multirow{2}{*}{0.022} \\
\hline Margin & Post-Merger & 14.39 & 8.74 & & \\
\hline Return on & Pre-Merger & 0.26 & 0.29 & \multirow{2}{*}{-2.37} & \multirow{2}{*}{0.031} \\
\hline Assets & Post-Merger & 0.59 & 0.40 & & \\
\hline Return on & Pre-Merger & 2.80 & 3.08 & \multirow{2}{*}{-2.64} & \multirow{2}{*}{0.019} \\
\hline Net Worth & Post-Merger & 6.84 & 4.81 & & \\
\hline Debt Equity & Pre-Merger & 996.57 & 121.47 & 0.46 & 0.655 \\
\hline
\end{tabular}




\begin{tabular}{llllll}
\hline Ratio & Post-Merger & 968.65 & 242.98 & & \\
Return on & Pre-Merger & 63.54 & 57.00 & -2.24 & 0.041 \\
Staff Expenses & Post-Merger & 131.91 & 76.77 & & \\
Return on Loan & Pre-Merger & 50.92 & 54.42 & -2.42 & 0.028 \\
Loss Provisions & Post-Merger & 342.34 & 463.86 & & \\
Return on & Pre-Merger & 24.96 & 22.91 & & \\
Operating & Post-Merger & 62.00 & 38.17 & -2.66 & 0.018 \\
Expenses & & & & & \\
\hline
\end{tabular}

For Machhapuchchhre Bank Limited 4 year's quarterly data are pooled and analyzed. Here, as a result of the merger, all the ratios seem to have improved. The reason may be merging with a strong capital based entity or operational efficiency. It can be observed that Net profit margin, Return on assets, Return on net worth, Return on staff expenses, Return on loan loss provision and return on operating expenses are significantly different in pre and post-merger period, i.e. they have displayed improvements after the merger.

Table 4: Paired sample t-test of operating ratios of NIC Asia bank limited

\begin{tabular}{llllll}
\hline Particulars & Period & Mean & Std. Deviation & t-value & Value \\
\hline Operating Profit & Pre-Merger & 35.80 & 7.36 & 4.22 & 0.001 \\
Margin & Post-Merger & 26.53 & 4.88 & & \\
Net Profit Margin & Pre-Merger & 19.44 & 8.17 & -0.08 & 0.94 \\
& Post-Merger & 19.64 & 3.40 & & \\
Return on Assets & Pre-Merger & 1.04 & 0.53 & 0.89 & 0.391 \\
& Post-Merger & 0.89 & 0.45 & & \\
Return on Net Worth & Pre-Merger & 11.66 & 5.70 & 1.47 & 0.169 \\
& Post-Merger & 9.06 & 4.71 & & \\
Debt Equity Ratio & Pre-Merger & 1028.92 & 105.78 & 3.01 & 0.012 \\
Return on Staff & Post-Merger & 922.76 & 115.38 & & \\
Expenses & Pre-Merger & 270.67 & 152.07 & 1.66 & 0.124 \\
Return on & Post-Merger & 197.29 & 47.74 & & \\
Loan Loss Provisions & Pre-Merger & 1411.63 & 1133.72 & 3.17 & 0.009 \\
Return on & Post-Merger & 334.30 & 245.38 & & \\
Operating Expenses & Pre-Merger & 124.42 & 66.57 & 1.33 & 0.21 \\
\hline
\end{tabular}

Quarterly data of 3 years are pooled and analyzed for NIC Asia Bank Limited. Similar to Nepal Bangladesh Bank Limited majority of the ratios i.e.7 out of 8 seem to have deteriorated after the merger. From the p-value, only operating profit margin, debt equity ratio and return on loan loss provision appear significantly different while comparing the pre and post-merger period. The overall performance of NIC Asia bank appears to be declining in post-merger. 
Table 5: Paired sample t-test of operating ratios of overall Commercial bank sector

\begin{tabular}{|c|c|c|c|c|c|}
\hline Particulars & Period & Mean & $\begin{array}{l}\text { Std. } \\
\text { Deviation }\end{array}$ & t-value & P-Value \\
\hline Operating Profit & Pre-Merger & 25.34 & 19.56 & \multirow{2}{*}{3.59} & \multirow{2}{*}{0.134} \\
\hline Margin & Post-Merger & 21.00 & 13.44 & & \\
\hline Net Profit & Pre-Merger & 40.84 & 52.43 & \multirow{2}{*}{4.12} & \multirow{2}{*}{0.007} \\
\hline Margin & Post-Merger & 21.47 & 10.91 & & \\
\hline \multirow{2}{*}{ Return on Assets } & Pre-Merger & 2.22 & 3.91 & \multirow{2}{*}{2.88} & \multirow{2}{*}{0.015} \\
\hline & Post-Merger & 0.96 & 0.86 & & \\
\hline \multirow{2}{*}{ Return on Net Worth } & Pre-Merger & 2.62 & 87.40 & \multirow{2}{*}{-0.43} & \multirow{2}{*}{0.625} \\
\hline & Post-Merger & 8.78 & 6.13 & & \\
\hline \multirow{2}{*}{ Debt Equity Ratio } & Pre-Merger & 616.76 & 1436.07 & \multirow{2}{*}{-1.19} & \multirow{2}{*}{0.326} \\
\hline & Post-Merger & 815.82 & 223.01 & & \\
\hline Return on Staff & Pre-Merger & 349.25 & 429.50 & \multirow{2}{*}{3.60} & \multirow{2}{*}{0.006} \\
\hline Expenses & Post-Merger & 180.84 & 82.45 & & \\
\hline Return on Loan & Pre-Merger & 580.00 & 806.57 & \multirow{2}{*}{1.67} & \multirow{2}{*}{0.078} \\
\hline Loss Provisions & Post-Merger & 359.17 & 374.36 & & \\
\hline Return on & Pre-Merger & 178.39 & 231.51 & \multirow{2}{*}{3.50} & \multirow{2}{*}{0.009} \\
\hline Operating Expenses & Post-Merger & 93.63 & 45.43 & & \\
\hline
\end{tabular}

After analyzing the data for individual sample banks all the data are pooled together for overall commercial banking sector. Similar to Nepal Bangladesh Bank and NIC Asia Bank, the overall commercial banking sector doesn't seem to be doing well from the merger. Majority of the ratios, i.e. 6 out of 8 , have fallen in post-merger indicating decline in performance. There appears significant difference in the performance in pre and post-merger period in terms of net profit margin, return on assets, return on staff expenses and return on operating expenses as indicated by the $\mathrm{p}$-value.

\subsection{Inferential Analysis}

Regression analysis helps one understand how the typical value of the dependent variable changes when any one of the independent variables is varied, while the other independent variables are held fixed. Using the regression the researcher is trying to identify the significance of operating ratios/performance on the profitability of overall commercial banking industry. The researcher compares the impact of operating ratios on profitability before and after the merger and whether their extent of contribution are significant even post-merger. For the purpose of regression Net profit margin and Return on assets are considered as dependent variables and Debt equity ratio, Return on loan loss provisions and Return on operating expenses are taken as independent variables. 
In order to avoid multicollinearity, i.e. high intercorrelations or inter-associations among the independent variables which if present in the data the statistical inferences made about the data may not be reliable, correlation analysis and VIF test are performed before performing regression analysis.

From the correlation analysis, if the correlation between two variables is high, then most data analysts would say that there is a problematic collinearity. In this study, correlation of 0.5 or more is considered as a high correlation.

To identify the multicollinearity, correlation analysis is conducted as shown in table 6. By removing variables that are highly collinear, other independent variables are included for regression.

Table 6: Correlation analysis of independent variables

\begin{tabular}{|c|c|c|c|c|c|c|c|}
\hline \multicolumn{2}{|c|}{$\begin{array}{l}\text { Independent } \\
\text { Variables }\end{array}$} & $\begin{array}{l}\text { Operating } \\
\text { Profit } \\
\text { Margin }\end{array}$ & $\begin{array}{l}\text { Return } \\
\text { on Net } \\
\text { Worth }\end{array}$ & $\begin{array}{l}\text { Debt } \\
\text { Equity } \\
\text { Ratio }\end{array}$ & $\begin{array}{l}\text { Return } \\
\text { on Staff } \\
\text { Expenses }\end{array}$ & $\begin{array}{l}\text { Return on } \\
\text { Loan Loss } \\
\text { Provisions }\end{array}$ & $\begin{array}{l}\text { Return on } \\
\text { Operating } \\
\text { Expenses }\end{array}$ \\
\hline \multicolumn{8}{|l|}{ Operating } \\
\hline Profit & Pearson & & & & & & \\
\hline Margin & Correlation & 1 & 0.053 & -0.161 & $.755^{* *}$ & $.559 * *$ & $.733 * *$ \\
\hline Return on & Pearson & & & & & & \\
\hline $\begin{array}{l}\text { Net Worth } \\
\text { Debt }\end{array}$ & Correlation & 0.053 & 1 & $.786^{* *}$ & 0.113 & 0.103 & 0.102 \\
\hline Equity & Pearson & & & & & & \\
\hline $\begin{array}{l}\text { Ratio } \\
\text { Return on }\end{array}$ & Correlation & -0.161 & $.786^{* *}$ & 1 & -0.262 & 0.01 & -0.278 \\
\hline Staff & Pearson & & & & & & \\
\hline $\begin{array}{l}\text { Expenses } \\
\text { Return on }\end{array}$ & Correlation & $.755^{* *}$ & 0.113 & -0.262 & 1 & $.382 * *$ & $.998 * *$ \\
\hline Loan Loss & Pearson & & & & & & \\
\hline $\begin{array}{l}\text { Provisions } \\
\text { Return on }\end{array}$ & Correlation & $.559 * *$ & 0.103 & 0.01 & $.382 * *$ & 1 & $.347^{*}$ \\
\hline Operating & Pearson & & & & & & \\
\hline Expenses & Correlation & $.733 * *$ & 0.102 & -0.278 & $.998 * *$ & $.347 *$ & 1 \\
\hline
\end{tabular}

** Correlation is significant at the 0.01 level (2-tailed).

* Correlation is significant at the 0.05 level (2-tailed). 
Pathak: An Analysis of Outpatients' Perceived Service Quality

Table 7: Correlation analysis of independent variables

\begin{tabular}{|c|c|c|c|c|}
\hline \multicolumn{2}{|c|}{ Independent Variables } & $\begin{array}{l}\text { Debt } \\
\text { Equity } \\
\text { Ratio }\end{array}$ & $\begin{array}{l}\text { Return on } \\
\text { Loan Loss } \\
\text { Provisions } \\
\end{array}$ & $\begin{array}{l}\text { Return on } \\
\text { Operating } \\
\text { Expenses } \\
\end{array}$ \\
\hline $\begin{array}{l}\text { Debt Equity Ratio } \\
\text { Return on Loan }\end{array}$ & Pearson Correlation & 1 & 0.01 & -0.278 \\
\hline $\begin{array}{l}\text { Loss Provisions } \\
\text { Return on }\end{array}$ & Pearson Correlation & 0.01 & 1 & $.347^{*}$ \\
\hline Operating Expenses & Pearson Correlation & -0.278 & $.347 *$ & 1 \\
\hline
\end{tabular}

Now, if we look at the table 7, Pearson correlation by removing highly correlated independent variables, then there is insignificant correlation among the independent variables.

Along with the correlation analysis, VIF (Variance Inflation Factor) test is also performed and the results are displayed and operating ratios having a VIF score greater than 10 are removed from the independent variables (see table 8). VIF measure how much the variance of the estimated regression coefficients are inflated as compared to when the independent variables are not linearly related.

Table 8: VIF test of independent variables

\begin{tabular}{lll}
\hline Independent Variables & Tolerance & VIF \\
\hline Operating Profit Margin & 0.309 & 3.232 \\
Return on Net Worth & 0.263 & 3.803 \\
Debt Equity Ratio & 0.243 & 4.122 \\
Return on Staff Expenses & 0.003 & 344.77 \\
Return on Loan Loss Provisions & 0.565 & 1.769 \\
Return on Operating Expenses & 0.003 & 325.275 \\
\hline
\end{tabular}

Some of the ratios have a VIF score of greater than 100 which shows a clear sign of multicollinearity between the variables. This relation can also be observed from the correlation test.

Table 9: VIF test of independent variables

\begin{tabular}{lll}
\hline Independent Variables & Tolerance & VIF \\
\hline Debt Equity Ratio & 0.91 & 1.099 \\
Return on Loan Loss Provisions & 0.867 & 1.153 \\
Return on Operating Expenses & 0.801 & 1.249 \\
\hline
\end{tabular}

From the table 9, it can be seen that the VIF scores are close to 1, which indicates independent variables are not correlated. From both the correlation analysis and VIF test, three independent variables are selected for the regression analysis to analyze their impact on the profitability. 
Table 10: Significance of operating ratios on net profit margin

\begin{tabular}{|c|c|c|c|c|c|c|}
\hline Case & $\begin{array}{l}\text { Dependent } \\
\text { Variable }\end{array}$ & $\begin{array}{l}\text { Independent } \\
\text { Variables }\end{array}$ & $\begin{array}{l}\text { Adjusted } \\
\text { R Square }\end{array}$ & $\begin{array}{l}\text { Standardized } \\
\text { Coefficients } \\
\text { Beta }\end{array}$ & t-value & $\begin{array}{l}\text { p- } \\
\text { value }\end{array}$ \\
\hline \multirow{3}{*}{$\begin{array}{l}\text { Pre- } \\
\text { merger }\end{array}$} & \multirow{3}{*}{$\begin{array}{l}\text { Net Profit } \\
\text { Margin }\end{array}$} & Debt Equity Ratio & \multirow{3}{*}{0.933} & -0.112 & -2.822 & 0.007 \\
\hline & & $\begin{array}{l}\text { Return on Loan } \\
\text { Loss Provisions } \\
\text { Return on }\end{array}$ & & -0.131 & -3.224 & 0.002 \\
\hline & & $\begin{array}{l}\text { Operating } \\
\text { Expenses }\end{array}$ & & 0.967 & 22.839 & 0 \\
\hline \multirow{3}{*}{$\begin{array}{l}\text { Post- } \\
\text { merger }\end{array}$} & \multirow{3}{*}{$\begin{array}{l}\text { Net Profit } \\
\text { Margin }\end{array}$} & Debt Equity Ratio & \multirow{3}{*}{0.938} & -0.087 & -2.241 & 0.03 \\
\hline & & $\begin{array}{l}\text { Return on Loan } \\
\text { Loss Provisions } \\
\text { Return on }\end{array}$ & & 0.119 & 2.656 & 0.011 \\
\hline & & $\begin{array}{l}\text { Operating } \\
\text { Expenses }\end{array}$ & & 0.873 & 18.683 & 0 \\
\hline
\end{tabular}

From table 10, the adjusted r-square indicates that the three independent variables explain $93.3 \%$ variation in the dependent variable i.e. the net profit margin before the merger. Also the p-value indicates that there is significant impact of the selected independent variables on net profit margin. Similarly in the post-merger period, it can be observed that there are not many changes in both the value of $r$ square and the significance of the independent variable on net profit margin remains consistent.

Table 11: Significance of operating ratios on return on assets

\begin{tabular}{|c|c|c|c|c|c|c|}
\hline Case & $\begin{array}{l}\text { Dependent } \\
\text { Variable }\end{array}$ & $\begin{array}{l}\text { Independent } \\
\text { Variables }\end{array}$ & $\begin{array}{l}\text { Adjusted } \\
\text { R Square }\end{array}$ & $\begin{array}{l}\text { Standardized } \\
\text { Coefficients } \\
\text { Beta }\end{array}$ & t-value & p-value \\
\hline \multirow{3}{*}{ Pre-merger } & \multirow{3}{*}{$\begin{array}{l}\text { Return on } \\
\text { Assets }\end{array}$} & $\begin{array}{l}\text { Debt Equity } \\
\text { Ratio }\end{array}$ & \multirow{3}{*}{0.875} & 0.031 & 0.567 & 0.573 \\
\hline & & $\begin{array}{l}\text { Return on Loan } \\
\text { Loss Provisions } \\
\text { Return on }\end{array}$ & & -0.103 & -1.864 & 0.069 \\
\hline & & $\begin{array}{l}\text { Operating } \\
\text { Expenses }\end{array}$ & & 0.979 & 17.01 & 0 \\
\hline \multirow{3}{*}{ Post- merger } & \multirow{3}{*}{$\begin{array}{l}\text { Return on } \\
\text { Assets }\end{array}$} & $\begin{array}{l}\text { Debt Equity } \\
\text { Ratio }\end{array}$ & \multirow{3}{*}{0.652} & -0.083 & -0.893 & 0.377 \\
\hline & & $\begin{array}{l}\text { Return on Loan } \\
\text { Loss Provisions } \\
\text { Return on }\end{array}$ & & 0.025 & 0.237 & 0.814 \\
\hline & & $\begin{array}{l}\text { Operating } \\
\text { Expenses }\end{array}$ & & 0.779 & 7.022 & 0 \\
\hline
\end{tabular}


From table 11, the adjusted r-square shows that the independent variables explain $87.5 \%$ changes in return on assets. The p-value indicates that only return on operating expenses has significant impact on the dependent variables in case of pre-merger. Whereas, in the case of post-merger the adjusted r-square has weakened significantly indicating the decline in strength of independent variables in explaining the variation in dependent variable. Similar to the case of pre-merger, only return on operating expenses has a significant impact on return on assets after merger as well.

Result of this research is slightly contrasted with key paper which suggested that relative size of merged or acquired institution is the main factor for success of merger but this study suggests that despite of its size, its financial health and proper synchronizing of merging institutions are more important factor for a successful merger. The reason behind the contrast in the result may be categorization of institutions on the basis of their relative size by Mantravadi and Reddy (2007) and random selection of three merged banks by the researcher. Despite the small sample size, due to lack of previous published articles, the results of this research will assist the policy makers and several stakeholders of banking and financial institutions.

\section{Concluding Remarks}

This study observed that merger has acted as most significant tool for Machapuchchhre Bank Ltd. as all of its operating performance ratios have been improved in post-merger. But for Nepal Bangladesh Bank and NIC Asia Bank the case is just opposite and has been found deteriorating in almost all the operating performance ratios in post-merger. The case for overall commercial bank sector is similar to that of Nepal Bangladesh Bank and NIC Asia, i.e. the performance of overall commercial bank sector goes downhill in post-merger. Significant difference can be observed in majority of the operating performance ratios before and after the merger, although it may be improvement or deterioration. Further regression analysis shows that all the selected independent variables (operating ratios) have significant impact on net profit margin and their significance does not differ much in pre and post-merger period. Whereas, only return on operating expense has huge impact on return on assets but debt equity ratio and return on loan loss provision have insignificant impact. This is true for both pre and postmerger periods.

The success or failure of merger to a large extent depends on the financial strength and position of the merging entities prior to merger. Merger was successful for those entities that had complementary financial status with its target partners and failure for those which had to carry the financial burden such as debt of its target 
partners. It has shown both aspects of success and failure of merger in the Nepalese Banking.

The analysis reveals that merger plays an important role in solving problems such as, increasing capital base, making the BFIs financially strong, reducing the number of BFIs and so on. But it is also observed that merger may not have positive impact on operating performance for every institution. Another problem faced by the BFIs is selecting the right partner for merger and agreeing on terms and conditions to implement merger. Banks have been blacklisted by NRB for continuing the talks of merger for months but not following through with it due to lack of consensus on terms of merger. Commercial banks that have not met the Rs 8 billion paid-up capital mark are under a lot of stress to find the correct merging partners but finding them is not the ultimate problem, the problem is to make the merger a successful and profitable one.

This study, however, has a weakness as the sample used in the study is relatively smaller which provides an opportunity to other researchers to take a wider sample for better results. But in the absence of other published studies for impact of merger, this research will serve as a basis for more intensive study for policy makers and scholars alike.

\section{References}

Abdulazeez, D. A., Suleiman, O., \& Yahaya, A. (2016). Impact of merger and acquisitions on the financial performance of deposit money banks in Nigeria. Arabian Journal of Business and Management Review, 6(4), 1-5.

Adhikari, S. (2014). Merger and acquisition as an indispensable tool for strengthening Nepalese banking and financial institutions (unpublished thesis) Lapland University of Applied Sciences.

Altunbas, Y., \& Marques, D. (2008). Merger and acquisition and bank performance in Europe-The role of strategic similarities. Journal of Economics and Business, 60(3), 204-222.

Cornett, M. M., McNutt, J. J., \& Tehranian, H. (2006). Performance changes around bank mergers: Revenue enhancements versus cost reductions. Journal of Money, Credit and Banking, 38(4), 1013-1050.

Gyanwali, B.M. (2011). Merger by-laws. Press Conference at Nepal Rastra Bank on May 2011.

Kemal, M. U. (2011). Post-merger profitability: A case of Royal Bank of Scotland (RBS). International Journal of Business and Social Science,2(5), 157-162. 
Mantravadi, P., \& Reddy, A. V. (2008). Type of merger and impact on operating performance: The Indian experience. Economic and Political Weekly, 43(39), 66-74.

Mantravadi, P., \& Reddy, A.V. (2007). Relative size in mergers and operating performance: Indian experience. Economic and Political Weekly, 42(39), 3936-3942.

Pazarskis, M., Vogiatzogloy, K., Christodoulu, P., \&Drogalas, I. (2006). Exploring the improvement of corporate performance after mergers-the case of Greece. International Research Journal of Finance and Economics, 6(22), 184-192.

Peristiani, S. (1997). Do mergers improve the X-efficiency and scale efficiency of US banks? Evidence from the 1980s. Journal of Money, Credit and Banking, 29(3), 326-337.

Rani, N., Yadav, S. S., \& Jain, P. K. (2015). Financial performance analysis of mergers and acquisitions: Evidence from India. International Journal of Commerce and Management, 25(4), 402-423.

Share Bazar Nepal (2013). Financial institution: Merger and merged. Retrieved from https://www.sharebazarnepal.com.np/views/articles/392-financialinstitution-merger-merged.html.

Sharma, N. (2014). Extent of corporate governance disclosure by banks and finance companies listed on Nepal Stock Exchange. Advances in Accounting, 30(2), 425-439.

Shrestha, P.M. (2012, July). Thinking of linking: Mergers on the rise in Nepali banking sector. The Kathmandu Post. Retrieved from http://kathmandupost.ekantipur.com/ printedition/ news/ 2012-07-17/thinkingof-linking-mergers-on-the-rise-in-nepali-banking-sector.html. 
Annexure

Annex 1: Pre-merger operating ratios of NBB

\begin{tabular}{|c|c|c|c|c|c|c|c|c|c|}
\hline Year & Quarter & $\begin{array}{l}\text { Operating } \\
\text { Profit } \\
\text { Margin }\end{array}$ & $\begin{array}{l}\text { Net } \\
\text { Profit } \\
\text { Margin }\end{array}$ & $\begin{array}{l}\text { Return } \\
\text { On } \\
\text { Assets }\end{array}$ & $\begin{array}{l}\text { Return } \\
\text { On Net } \\
\text { Worth }\end{array}$ & $\begin{array}{l}\text { Debt } \\
\text { Equity } \\
\text { Ratio }\end{array}$ & $\begin{array}{l}\text { Return } \\
\text { On Staff } \\
\text { Expenses }\end{array}$ & $\begin{array}{l}\text { Return on } \\
\text { Loan Loss } \\
\text { Provisions }\end{array}$ & $\begin{array}{l}\text { Return On } \\
\text { Operating } \\
\text { Expenses }\end{array}$ \\
\hline \multirow[t]{2}{*}{2006} & $3^{\text {rd }}$ & 25.42 & 24.18 & 0.96 & 36.79 & 3721.68 & 170.92 & 0.00 & 80.95 \\
\hline & $4^{\text {th }}$ & 37.11 & 30.50 & 2.01 & 55.41 & 2652.77 & 305.85 & 446.25 & 135.14 \\
\hline \multirow[t]{4}{*}{2007} & $1^{\text {st }}$ & 12.86 & 12.29 & 0.15 & 4.07 & 2666.25 & 109.98 & 128.04 & 48.63 \\
\hline & $2^{\text {nd }}$ & -14.85 & -28.03 & -1.11 & 8.94 & -903.21 & -244.45 & -50.97 & -113.40 \\
\hline & $3^{\text {rd }}$ & 28.40 & 12.91 & 0.88 & -5.71 & -747.16 & 128.96 & 54.36 & 55.44 \\
\hline & $4^{\text {th }}$ & 52.26 & 39.34 & 3.88 & -33.57 & -964.88 & 415.49 & 623.48 & 185.18 \\
\hline \multirow[t]{4}{*}{2008} & $1^{\text {st }}$ & 6.83 & 36.37 & 0.53 & -4.59 & -966.31 & 169.83 & 105.88 & 90.97 \\
\hline & $2^{\text {nd }}$ & 62.53 & 156.30 & 5.49 & -24.93 & -554.16 & 980.09 & 0.00 & 523.33 \\
\hline & $3^{\text {rd }}$ & 20.69 & 102.16 & 5.22 & -22.97 & -540.42 & 580.16 & 318.93 & 313.60 \\
\hline & $4^{\text {th }}$ & 62.72 & 184.89 & 18.23 & 173.33 & 850.69 & 1844.96 & 1341.03 & 983.80 \\
\hline \multirow[t]{4}{*}{2009} & $1^{\text {st }}$ & 13.97 & 118.89 & 1.86 & -8.86 & -575.97 & 490.35 & 329.72 & 258.24 \\
\hline & $2^{\text {nd }}$ & 45.15 & 134.59 & 4.36 & -36.64 & -940.13 & 836.13 & 716.61 & 443.59 \\
\hline & $3^{\text {rd }}$ & 43.63 & 130.38 & 7.68 & -531.91 & -7022.24 & 937.83 & 626.79 & 511.84 \\
\hline & $4^{\text {th }}$ & 62.72 & 184.89 & 18.23 & 173.33 & 850.69 & 1844.96 & 1341.03 & 983.80 \\
\hline \multirow[t]{4}{*}{2010} & $1^{\text {st }}$ & 23.13 & 85.58 & 1.61 & 13.27 & 725.50 & 541.58 & 296.55 & 332.44 \\
\hline & $2^{\text {nd }}$ & 37.89 & 124.70 & 4.35 & 37.41 & 759.40 & 1062.96 & 635.28 & 570.88 \\
\hline & $3^{\text {rd }}$ & 40.95 & 100.35 & 5.42 & 41.71 & 669.40 & 860.52 & 668.65 & 450.37 \\
\hline & $4^{\text {th }}$ & 44.96 & 87.13 & 7.35 & 47.77 & 550.36 & 693.75 & 744.59 & 369.39 \\
\hline \multirow[t]{2}{*}{2011} & $1^{\text {st }}$ & 38.60 & 49.02 & 0.99 & 6.46 & 552.68 & 372.24 & 1204.56 & 222.82 \\
\hline & $2^{\text {nd }}$ & 37.38 & 45.45 & 1.88 & 11.79 & 527.20 & 396.95 & 554.68 & 223.33 \\
\hline
\end{tabular}

Annex 2: Post-merger operating ratios of NBB

\begin{tabular}{|c|c|c|c|c|c|c|c|c|c|}
\hline Year & Quarter & $\begin{array}{l}\text { Operating } \\
\text { Profit } \\
\text { Margin } \\
\end{array}$ & $\begin{array}{l}\text { Net } \\
\text { Profit } \\
\text { Margin }\end{array}$ & $\begin{array}{l}\text { Return } \\
\text { On } \\
\text { Assets } \\
\end{array}$ & $\begin{array}{l}\text { Return } \\
\text { On Net } \\
\text { Worth } \\
\end{array}$ & $\begin{array}{l}\text { Debt } \\
\text { Equity } \\
\text { Ratio } \\
\end{array}$ & $\begin{array}{l}\text { Return } \\
\text { On Staff } \\
\text { Expenses } \\
\end{array}$ & $\begin{array}{l}\text { Return on } \\
\text { Loan Loss } \\
\text { Provisions }\end{array}$ & $\begin{array}{l}\text { Return On } \\
\text { Operating } \\
\text { Expenses }\end{array}$ \\
\hline \multirow[t]{2}{*}{2011} & 3 rd & 7.51 & 19.23 & 1.24 & 9.56 & 671.99 & 171.96 & 50.38 & 95.80 \\
\hline & 4th & 14.78 & 28.95 & 2.61 & 18.38 & 604.59 & 219.34 & 98.36 & 126.49 \\
\hline \multirow[t]{4}{*}{2012} & $1 \mathrm{st}$ & 8.04 & 10.05 & 0.19 & 1.42 & 657.18 & 72.31 & 83.70 & 42.54 \\
\hline & $2 \mathrm{nd}$ & -3.17 & 15.03 & 0.59 & 4.37 & 643.64 & 121.05 & 49.90 & 68.82 \\
\hline & $3 \mathrm{rd}$ & 2.75 & 46.09 & 2.71 & 18.29 & 574.32 & 373.30 & 199.56 & 205.95 \\
\hline & 4 th & 24.13 & 52.94 & 3.89 & 27.40 & 603.56 & 401.86 & 1140.66 & 220.63 \\
\hline \multirow[t]{4}{*}{2013} & $1 \mathrm{st}$ & 3.83 & 17.19 & 0.31 & 2.03 & 559.05 & 111.87 & 115.12 & 63.20 \\
\hline & 2nd & 11.39 & 23.60 & 0.89 & 5.49 & 514.93 & 170.51 & 134.95 & 89.69 \\
\hline & $3 \mathrm{rd}$ & 19.98 & 27.48 & 1.64 & 9.52 & 481.06 & 202.80 & 185.82 & 107.79 \\
\hline & 4 th & 34.13 & 47.97 & 3.52 & 21.79 & 519.27 & 327.45 & 1174.39 & 179.40 \\
\hline \multirow[t]{4}{*}{2014} & $1 \mathrm{st}$ & 26.10 & 28.28 & 0.55 & 3.81 & 588.85 & 234.89 & 332.76 & 126.39 \\
\hline & 2 nd & 29.04 & 27.79 & 0.93 & 7.05 & 661.78 & 223.22 & 262.99 & 124.79 \\
\hline & $3 \mathrm{rd}$ & 26.50 & 27.94 & 1.40 & 10.11 & 622.66 & 215.51 & 201.45 & 120.22 \\
\hline & 4 th & 37.51 & 36.52 & 2.37 & 18.06 & 662.95 & 235.89 & 882.30 & 135.40 \\
\hline \multirow[t]{4}{*}{2015} & $1 \mathrm{st}$ & 10.89 & 10.05 & 0.14 & 1.12 & 700.07 & 57.73 & 63.10 & 32.16 \\
\hline & $2 \mathrm{nd}$ & 38.93 & 31.33 & 0.97 & 7.46 & 667.29 & 215.37 & 815.70 & 117.75 \\
\hline & $3 \mathrm{rd}$ & 38.21 & 31.09 & 1.40 & 11.10 & 694.20 & 223.28 & 413.12 & 118.06 \\
\hline & 4th & 43.59 & 34.62 & 2.04 & 16.64 & 717.15 & 245.23 & 905.34 & 128.04 \\
\hline \multirow[t]{2}{*}{2016} & $1 \mathrm{st}$ & 24.77 & 20.86 & 0.30 & 2.49 & 743.35 & 148.06 & 301.34 & 84.10 \\
\hline & 2 nd & 36.39 & 27.93 & 0.88 & 7.01 & 699.86 & 230.68 & 339.93 & 130.89 \\
\hline
\end{tabular}


Annex 3: Pre-merger operating ratios of MBL

\begin{tabular}{|c|c|c|c|c|c|c|c|c|c|}
\hline Year & Quarter & $\begin{array}{l}\text { Operating } \\
\text { Profit } \\
\text { Margin }\end{array}$ & $\begin{array}{l}\text { Net } \\
\text { Profit } \\
\text { Margin }\end{array}$ & $\begin{array}{l}\text { Return } \\
\text { On } \\
\text { Assets }\end{array}$ & $\begin{array}{l}\text { Return } \\
\text { On Net } \\
\text { Worth }\end{array}$ & $\begin{array}{l}\text { Debt } \\
\text { Equity } \\
\text { Ratio }\end{array}$ & $\begin{array}{l}\text { Return } \\
\text { On Staff } \\
\text { Expenses }\end{array}$ & $\begin{array}{l}\text { Return on } \\
\text { Loan Loss } \\
\text { Provisions }\end{array}$ & $\begin{array}{l}\text { Return On } \\
\text { Operating } \\
\text { Expenses }\end{array}$ \\
\hline 2008 & 4 th & 25.63 & 15.96 & 1.01 & 10.38 & 926.71 & 180.25 & 126.48 & 64.56 \\
\hline \multirow[t]{4}{*}{2009} & $1 \mathrm{st}$ & 14.22 & 9.05 & 0.14 & 1.17 & 741.33 & 89.34 & 44.72 & 36.22 \\
\hline & 2nd & 8.59 & 5.46 & 0.17 & 1.50 & 782.36 & 59.88 & 21.87 & 21.13 \\
\hline & $3 \mathrm{rd}$ & 8.97 & 5.70 & 0.27 & 2.45 & 820.87 & 62.40 & 24.23 & 21.92 \\
\hline & 4th & 14.07 & 8.92 & 0.53 & 5.57 & 944.93 & 102.79 & 47.17 & 34.29 \\
\hline \multirow[t]{4}{*}{2010} & $1 \mathrm{st}$ & 13.11 & 14.14 & 0.25 & 2.79 & 1031.84 & 126.98 & 116.22 & 58.53 \\
\hline & 2nd & 17.96 & 14.18 & 0.50 & 5.76 & 1050.68 & 149.40 & 199.80 & 63.93 \\
\hline & $3 \mathrm{rd}$ & 7.70 & 8.19 & 0.46 & 5.33 & 1063.53 & 89.03 & 59.29 & 37.61 \\
\hline & 4th & 7.75 & 7.57 & 0.60 & 7.00 & 1067.10 & 86.44 & 64.84 & 34.50 \\
\hline \multirow[t]{4}{*}{2011} & $1 \mathrm{st}$ & 2.70 & 1.90 & 0.04 & 0.53 & 1141.02 & 22.37 & 46.78 & 8.27 \\
\hline & $2 \mathrm{nd}$ & 0.40 & 0.35 & 0.02 & 0.19 & 1125.56 & 4.52 & 3.59 & 1.67 \\
\hline & $3 \mathrm{rd}$ & -5.31 & 0.68 & 0.05 & 0.58 & 1093.48 & 8.92 & 4.04 & 3.34 \\
\hline & 4 th & -4.13 & 0.40 & 0.04 & 0.46 & 1035.16 & 5.02 & 2.44 & 1.88 \\
\hline \multirow[t]{3}{*}{2012} & $1 \mathrm{st}$ & 2.39 & 1.52 & 0.04 & 0.41 & 990.06 & 16.59 & 31.85 & 6.85 \\
\hline & 2 nd & -5.79 & 0.64 & 0.03 & 0.32 & 1051.53 & 7.09 & 9.92 & 2.62 \\
\hline & $3 \mathrm{rd}$ & -4.02 & 0.50 & 0.03 & 0.37 & 1078.96 & 5.65 & 11.50 & 2.11 \\
\hline
\end{tabular}

Annex 4: post-merger operating ratios of $\mathrm{MBL}$

\begin{tabular}{|c|c|c|c|c|c|c|c|c|c|}
\hline Year & Quarter & $\begin{array}{l}\text { Operating } \\
\text { Profit } \\
\text { Margin }\end{array}$ & $\begin{array}{l}\text { Net } \\
\text { Profit } \\
\text { Margin }\end{array}$ & $\begin{array}{l}\text { Return } \\
\text { On } \\
\text { Assets }\end{array}$ & $\begin{array}{l}\text { Return } \\
\text { On Net } \\
\text { Worth }\end{array}$ & $\begin{array}{l}\text { Debt } \\
\text { Equity } \\
\text { Ratio }\end{array}$ & $\begin{array}{l}\text { Return } \\
\text { On Staff } \\
\text { Expenses }\end{array}$ & $\begin{array}{l}\text { Return on } \\
\text { Loan Loss } \\
\text { Provisions }\end{array}$ & $\begin{array}{l}\text { Return On } \\
\text { Operating } \\
\text { Expenses }\end{array}$ \\
\hline 2012 & $4^{\text {th }}$ & -23.13 & 0.56 & 0.04 & 0.41 & 849.48 & 6.56 & 1.85 & 2.29 \\
\hline \multirow[t]{4}{*}{2013} & $1^{\text {st }}$ & -0.33 & 1.17 & 0.03 & 0.26 & 862.53 & 10.38 & 6.17 & 4.46 \\
\hline & $2^{\text {nd }}$ & 3.42 & 2.99 & 0.13 & 1.23 & 879.72 & 29.06 & 18.63 & 11.84 \\
\hline & $3^{\text {rd }}$ & 3.81 & 5.64 & 0.34 & 3.51 & 920.74 & 57.37 & 29.31 & 23.07 \\
\hline & $4^{\text {th }}$ & 5.59 & 6.12 & 0.48 & 5.29 & 1003.96 & 63.54 & 33.16 & 24.77 \\
\hline \multirow[t]{4}{*}{2014} & $1^{\mathrm{st}}$ & 4.61 & 10.24 & 0.20 & 2.35 & 1050.20 & 89.79 & 84.38 & 43.64 \\
\hline & $2^{\text {nd }}$ & 18.73 & 15.11 & 0.58 & 6.80 & 142.29 & 154.76 & 315.02 & 68.33 \\
\hline & $3^{\text {rd }}$ & 19.28 & 15.49 & 0.82 & 10.20 & 1139.56 & 163.82 & 277.46 & 69.62 \\
\hline & $4^{\text {th }}$ & 20.17 & 16.03 & 1.12 & 14.05 & 1158.10 & 162.48 & 266.35 & 68.77 \\
\hline \multirow[t]{4}{*}{2015} & $1^{\mathrm{st}}$ & 25.72 & 24.87 & 0.45 & 5.56 & 1136.89 & 231.63 & 352.08 & 112.68 \\
\hline & $2^{\text {nd }}$ & 26.43 & 22.98 & 0.76 & 9.11 & 1098.49 & 223.52 & 321.22 & 100.69 \\
\hline & $3^{\text {rd }}$ & 23.98 & 19.35 & 0.93 & 10.88 & 1068.87 & 195.33 & 200.22 & 86.58 \\
\hline & $4^{\text {th }}$ & 23.82 & 19.85 & 1.24 & 15.24 & 1125.96 & 171.84 & 311.77 & 79.68 \\
\hline \multirow[t]{3}{*}{2016} & $1^{\text {st }}$ & 31.57 & 20.99 & 0.33 & 3.95 & 1080.94 & 160.85 & 789.84 & 91.02 \\
\hline & $2^{\text {nd }}$ & 36.21 & 24.09 & 0.76 & 8.46 & 1007.00 & 203.85 & 1870.35 & 105.21 \\
\hline & $3^{\text {rd }}$ & 34.33 & 24.72 & 1.14 & 12.22 & 973.67 & 185.74 & 599.65 & 99.32 \\
\hline
\end{tabular}


Annex 5: Pre-merger operating ratios of NIC Asia

\begin{tabular}{|c|c|c|c|c|c|c|c|c|c|}
\hline Year & Quarter & $\begin{array}{l}\text { Operating } \\
\text { Profit } \\
\text { Margin } \\
\end{array}$ & $\begin{array}{l}\text { Net } \\
\text { Profit } \\
\text { Margin } \\
\end{array}$ & $\begin{array}{l}\text { Return } \\
\text { On } \\
\text { Assets } \\
\end{array}$ & $\begin{array}{l}\text { Return } \\
\text { On Net } \\
\text { Worth } \\
\end{array}$ & $\begin{array}{l}\text { Debt } \\
\text { Equity } \\
\text { Ratio } \\
\end{array}$ & $\begin{array}{l}\text { Return } \\
\text { On Staff } \\
\text { Expenses } \\
\end{array}$ & $\begin{array}{l}\text { Return on } \\
\text { Loan Loss } \\
\text { Provisions } \\
\end{array}$ & $\begin{array}{l}\text { Return } \\
\text { On } \\
\text { Operating } \\
\text { Expenses } \\
\end{array}$ \\
\hline 2010 & 4th & 38.799 & 25.473 & 2.229 & 21.426 & 861.179 & 380.888 & 2551.807 & 178.141 \\
\hline \multirow[t]{4}{*}{2011} & $1 \mathrm{st}$ & 35.868 & 23.788 & 0.690 & 7.353 & 966.192 & 400.675 & 2842.037 & 185.461 \\
\hline & 2 nd & 52.459 & 39.993 & 1.258 & 12.929 & 927.667 & 659.344 & 3883.766 & 290.506 \\
\hline & $3 \mathrm{rd}$ & 45.432 & 9.928 & 0.364 & 4.004 & 1000.710 & 106.957 & 442.775 & 50.980 \\
\hline & 4th & 35.859 & 12.182 & 0.518 & 5.705 & 1001.866 & 96.186 & 545.947 & 51.423 \\
\hline \multirow[t]{4}{*}{2012} & $1 \mathrm{st}$ & 36.312 & 14.243 & 0.840 & 8.847 & 953.637 & 217.768 & 813.058 & 105.801 \\
\hline & 2 nd & 28.704 & 12.814 & 0.854 & 10.573 & 1137.583 & 191.998 & 705.585 & 83.246 \\
\hline & $3 \mathrm{rd}$ & 29.186 & 14.980 & 1.279 & 17.245 & 1248.255 & 223.023 & 836.802 & 102.096 \\
\hline & 4th & 25.305 & 16.112 & 1.532 & 18.998 & 1140.378 & 217.912 & 794.539 & 100.178 \\
\hline \multirow[t]{3}{*}{2013} & $1 \mathrm{st}$ & 33.024 & 21.008 & 0.495 & 5.610 & 1033.843 & 246.058 & 2086.991 & 117.397 \\
\hline & $2 \mathrm{nd}$ & 33.992 & 20.637 & 0.986 & 11.441 & 1060.624 & 223.747 & 659.168 & 99.341 \\
\hline & $3 \mathrm{rd}$ & 34.704 & 22.150 & 1.413 & 15.757 & 1015.106 & 283.510 & 777.091 & 128.525 \\
\hline
\end{tabular}

Annex 6: Post-merger operating ratios of NIC Asia

\begin{tabular}{|c|c|c|c|c|c|c|c|c|c|}
\hline Year & Quarter & $\begin{array}{l}\text { Operating } \\
\text { Profit } \\
\text { Margin }\end{array}$ & $\begin{array}{l}\text { Net } \\
\text { Profit } \\
\text { Margin }\end{array}$ & $\begin{array}{l}\text { Return } \\
\text { On } \\
\text { Assets }\end{array}$ & $\begin{array}{l}\text { Return } \\
\text { On Net } \\
\text { Worth }\end{array}$ & $\begin{array}{l}\text { Debt } \\
\text { Equity } \\
\text { Ratio }\end{array}$ & $\begin{array}{l}\text { Return } \\
\text { On Staff } \\
\text { Expenses }\end{array}$ & $\begin{array}{l}\text { Return on } \\
\text { Loan Loss } \\
\text { Provisions }\end{array}$ & $\begin{array}{l}\text { Return } \\
\text { On } \\
\text { Operating } \\
\text { Expenses }\end{array}$ \\
\hline 2013 & $4^{\text {th }}$ & 36.72 & 24.11 & 1.38 & 13.24 & 859.39 & 286.07 & 724.77 & 137.53 \\
\hline \multirow[t]{4}{*}{2014} & $1^{\text {st }}$ & 22.78 & 14.50 & 0.32 & 2.71 & 751.92 & 157.46 & 201.26 & 80.92 \\
\hline & $2^{\text {nd }}$ & 26.11 & 19.22 & 0.86 & 6.89 & 703.05 & 229.72 & 206.99 & 113.29 \\
\hline & $3^{\text {rd }}$ & 28.77 & 21.21 & 1.35 & 12.51 & 826.60 & 256.73 & 244.92 & 123.75 \\
\hline & $4^{\text {th }}$ & 30.44 & 20.82 & 1.61 & 17.07 & 956.85 & 219.74 & 321.01 & 108.87 \\
\hline \multirow[t]{4}{*}{2015} & $1^{\text {st }}$ & 22.71 & 15.87 & 0.27 & 3.07 & 1015.98 & 138.74 & 155.86 & 73.79 \\
\hline & $2^{\text {nd }}$ & 24.68 & 18.60 & 0.66 & 6.89 & 950.72 & 176.29 & 203.87 & 88.30 \\
\hline & $3^{\text {rd }}$ & 26.25 & 19.81 & 1.02 & 10.55 & 934.93 & 187.64 & 252.71 & 92.25 \\
\hline & $4^{\text {th }}$ & 23.06 & 17.93 & 1.16 & 12.60 & 986.07 & 166.57 & 215.99 & 80.41 \\
\hline \multirow[t]{3}{*}{2016} & $1^{\text {st }}$ & 17.81 & 15.35 & 0.26 & 2.75 & 970.86 & 125.42 & 169.94 & 66.28 \\
\hline & $2^{\text {nd }}$ & 29.70 & 24.21 & 0.74 & 8.37 & 1028.15 & 215.86 & 942.45 & 111.33 \\
\hline & $3^{\text {rd }}$ & 29.29 & 24.01 & 1.02 & 12.14 & 1088.58 & 207.24 & 371.85 & 107.67 \\
\hline
\end{tabular}

